Saudi Journal of Biomedical Research

Abbreviated Key Title: Saudi J Biomed Res ISSN 2518-3214 (Print) |ISSN 2518-3222 (Online)

\title{
Relationship of Fish Consumption to Hair Mercury Levels of Pregnant Women
}

\author{
Rahmat Hidayat ${ }^{1}$, Hasnawati Amqam ${ }^{1 *}$, Rina Previana Amiruddin ${ }^{2}$, Anwar Daud $^{1}$, Anwar Mallongi ${ }^{1}$, Rafael Djajakusli $^{3}$ \\ ${ }^{1}$ Department of Environmental Health, Faculty of Public Health, Hasanuddin University, Indonesia \\ ${ }^{2}$ Mothers and Children Kartini Hospital Makassar, Indonesia \\ ${ }^{3}$ Department of Occupational Health and Safety, Faculty of Public Health, Hasanuddin University, Indonesia
}

DOI: $10.36348 /$ sjbr.2020.v05i10.001 | Received: 14.10 .2020 | Accepted: 29.10.2020 | Published: 30.10 .2020

*Corresponding author: Hasnawati Amqam

\section{Abstract}

Mercury $(\mathrm{Hg})$ is a natural chemical element found in the Earth's crust in three forms, namely elemental, inorganic and organic. Mercury is formed naturally through anthropogenic activities, volcanoes or seepage of groundwater through mercury deposits. Mercury exposure cause harm to pregnant women and the fetus. Some mercury compounds bioaccumulate and cross the placenta to the fetus. They also pollute colostrum and breast milk, causing severe health problems for newborns such as, disabled and a tendency to hyperactivity or autism. High fish consumption increase mercury levels in pregnant women. Fish intake during pregnancy is associated with mercury levels in hair in pregnant women, mainly the frequency of fish intake, types of fish and the amount of fish consumed. This study aims to determine the relationship between fish consumption and mercury levels in the hair of pregnant women. Hair samples were taken from 53 pregnant women in Bulukumba district using purposive sampling technique. Hair analysis used Atomic Absorption Spectrophotometer (AAS) AMA 254 with a wavelength of $253.7 \mu \mathrm{m}$. This research is analytic observational with a cross-sectional study design. The results showed that were $73.6 \%$ of mercury levels in the hair of pregnant women were abnormal, then $64.2 \%$ of pregnant women who consumed fish $>3$ times / week and $35.8 \%$ of fish consumption $<3$ times / week It is concluded that there was a significant relationship between fish consumption and mercury levels in the hair of pregnant women, but it was not significant for total fish consumption. The community is advised to use mercury friendly materials and tools and to the government to intensify education to vulnerable communities about the dangers of mercury in pregnant women.

Keywords: Fish consumption, Hair, Mercury exposure, Pregnant women.

Copyright $\odot \mathbf{2 0 2 0}$ The Author(s): This is an open-access article distributed under the terms of the Creative Commons Attribution 4.0 International License (CC BY-NC 4.0) which permits unrestricted use, distribution, and reproduction in any medium for non-commercial use provided the original author and source are credited.

\section{INTRODUCTION}

Mercury $(\mathrm{Hg})$ is a chemical element that occurs naturally in the Earth's crust in three chemical forms, namely elemental, inorganic and organic, in liquid form, silver-white, volatile at room temperature and easily mixes with other metals such as gold, silver and tin $[11,16]$. Mercury is formed naturally through anthropogenic activities, volcanoes or through seepage of groundwater through mercury deposits. Anthropogenic activities can lead to increased exposure to mercury and residue in the environment [22].

According to Egani et al., [3] anthropogenic activities that occurred in Pakistan caused mercury levels in the air through dust particles to have passed the safe threshold where measurement results in 22 different locations obtained $3000 \mathrm{ppb}$, high concentrations of mercury in the air. Study in Peru describes the anthropogenic source of mercury from gold mining, where the results of the examination of sediment and fish in rivers have passed the safe value required by WHO $(0.5 \mathrm{mg} \mathrm{kg}-1)$. The results of the investigation of mercury levels in sediment were $2.4 \mathrm{mg}$ $\mathrm{kg}-1$ and $1 \mathrm{mg} \mathrm{kg}-1$ in fish. The high concentration of mercury in sediment and fish is due to agricultural activities and gold mining around the river [24].

Cases of poisoning caused by mercury were reported in Turkey in 2013, where 179 children were hospitalized for mercury poisoning, and three people died [19]. In 2019 in Turkey there was mercury poisoning which resulted in 29 people being hospitalized and one person dying. Mercury poisoning that occurs in Turkey is caused by inhaling mercury vapour while practising in a laboratory using a thermometer containing mercury [7]. In Indonesia, cases of mercury poisoning have been reported in 
several places, such as the case of pollution in Buyat Bay due to contamination with the gold mining of PT. Newmont and PETI activities that pollute rivers in Central Kalimantan [20].

Mercury can enter the human body through an exposure mechanism known as "port d entry", namely the skin, respiration and digestion. Consumption of fish, use of amalgam in dentistry, use of cosmetics and smoking are problems that also contribute to increased exposure to mercury in the human body, especially pregnant women and children who are the groups most vulnerable to the impact of mercury exposure. The pathway of Mercury exposure into the body affects the form of the disturbance it causes. People who are exposed to mercury vapours can experience impaired brain function. The decline is caused by cortical disorders which have implications for the development of the nervous system. Nervous system disorders bring to some effects, such as psychological complications, emotional disturbances, as well as severe mental hyperactivity $[10,26]$.

Mercury exposure can also cause harm to pregnant women and the fetus they are carrying. According to Yoshida, Al-saleh et al., [1, 27] some mercury compounds bioaccumulated and passed through the placenta to the fetus. It also polluted the colostrum and breast milk and resulted in serious health problems for newborns in the form of babies being deformed and a tendency to hyperactivity or autism. Total mercury ( $\mathrm{THg}$ ) levels in hair and methyl mercury $\mathrm{MeHg}$ levels in umbilical cord blood increases significantly with increasing of frequency of fish consumption [15]. High fish consumption also rose the mercury levels in pregnant women [2]. Fish intake during pregnancy is associated with mercury levels in hair of pregnant women, especially the frequency intake, types of fish and the amount of fish consumed. So, this study aims to analyze the relationship between fish consumption and mercury levels in the hair of pregnant women in Bulukumba district.

\section{MATERIALS AND METHODS \\ Location and time of Research}

This research was conducted at the Regional General Hospital of H. Andi Sultan Daeng Radja, Yasira Mother and Child Hospital, Caile Public Health Center and Ponre Public Health Center, Bulukumba District. The study held from June to August 2020.

\section{Type of Research}

This study is analytical observational that explains the relationship between variables independent and dependent through hypothesis testing with a cross sectional study design.

\section{Population and Sample}

The population in this study were all pregnant women who visited H. Andi Sultan Daeng Radja Regional General Hospital, Yasira Mother and Child Hospital, Caile Public health Center and Ponre Public health Center, in Bulukumba district. Samples were selected based on inclusion criteria with purposive sampling techniques. Samples were pregnant women in the first trimester, second trimester and third trimester who planned to give birth in Bulukumba district. The number of samples in this study was 53 samples.

\section{Hair Sampling}

The method used in hair sampling had been applied in the previous study Schaefer et al., [25] 0.05 mg hair sample was taken from the occipital area of the head close to the scalp, Each lock of hair was then clamped at the base then cut with scissors, around 1-3 $\mathrm{cm}$ from the root hair or at most with the scalp. The hair was stored in a plastic bag until analysis.

\section{Hair Analysis Method}

The dry hair sample was weighed as much as $0.05 \mathrm{mg}$, the sample was put into a $50 \mathrm{ml}$ volumetric flask, then the volumetric flask was heated with an electric bath until the hair decomposed at a temperature of $300{ }^{\circ} \mathrm{C}, 5 \mathrm{ml}$ of $\mathrm{HNO}_{3}$ (p) was added to the sample then closed, homogenized by turning the pumpkin slowly. $5 \mathrm{ml}$ of HCL (p) was added and homogenized again, then heated with an electric bath for 2 hours at $300^{\circ} \mathrm{C}$, then filtered with Whatman filter paper with a diameter of $125 \mathrm{~mm}$ No. 40 Cat no.1440-125. Add $20 \%$ nitric acid, measure each sample with an AMA 254 Atomic Absorption Spectrophotometer (AAS) with a wavelength of $253.7 \mu \mathrm{m}$. Create a calibration curve then calculate the mercury level in units of $\mu \mathrm{g} / \mathrm{g}$. For standardization used the standard solution (SRM) 1702260100 brand KGaA made in Germany.

\section{Data analysis}

The data analysis used in this study is a bivariate analysis that relates the independent variable (fish consumption) and the dependent variable (hair mercury levels) using the Chi-Square test.

\section{RESULT}

At this stage, a bivariate analysis was carried out between the independent variables. In this case, the frequency of fish consumption with the dependent variable, namely mercury levels in the hair of pregnant women. The results of data processing using SPSS will be described as follows: 
Table-1: The Relationship between Fish Consumption Frequency and Hair Mercury Levels of Pregnant Women in Bulukumba District in 2020

\begin{tabular}{|c|c|c|c|c|c|c|c|}
\hline \multirow[t]{2}{*}{ Fish Consumption Frequency } & \multicolumn{4}{|c|}{ Mercury levels in hair } & \multirow{2}{*}{\multicolumn{2}{|c|}{$\begin{array}{l}\text { Total } \\
\mathbf{N}(\%)\end{array}$}} & \multirow[t]{2}{*}{$\mathbf{p}^{\mathrm{ab}}$} \\
\hline & \multicolumn{2}{|c|}{ Abnormal n (\%) } & \multicolumn{2}{|c|}{ Normal n (\%) } & & & \\
\hline \multirow{3}{*}{$\begin{array}{l}>3 \text { times / week } \\
<3 \text { times / week } \\
\text { Total }\end{array}$} & 21 & 61,8 & 13 & 38,2 & 34 & 100.0 & \multirow[t]{3}{*}{0,009} \\
\hline & 18 & 94,7 & 1 & 5,3 & 19 & 100.0 & \\
\hline & 39 & 73,6 & 14 & 26,4 & 53 & 100.0 & \\
\hline
\end{tabular}

Source: Primary Data, 2020

Note: a. Chi-Square test b. $\alpha<0,05$

Table-1 shows that out of 53 respondents, 34 respondents who frequently consumed fish $>3$ times/week and $61.8 \%$ had abnormal mercury levels (> $1 \mu \mathrm{g} / \mathrm{g})$ and 19 respondents who consumed $<3$ times/week which $94.7 \%$ of them had abnormal mercury levels $(>1 \mu \mathrm{g} / \mathrm{g})$. The p-value $(\mathrm{p})=0.009$ is significant at $(\mathrm{p}=0.009<\alpha 0.05)$. So it can be assumed that there is a relationship between the frequency of eating fish and mercury levels in the hair of pregnant women.

Table-2: The Relationship of Total Fish Consumption to Mercury Levels in Hair of Pregnant Women in Bulukumba District in 2020

\begin{tabular}{|c|c|c|c|c|c|c|c|}
\hline \multirow{2}{*}{$\begin{array}{l}\text { Total Fish } \\
\text { Consumption }\end{array}$} & \multicolumn{4}{|c|}{ Mercury levels in hair } & \multirow{2}{*}{\multicolumn{2}{|c|}{$\begin{array}{l}\text { Total } \\
\text { N }(\%) \\
\end{array}$}} & \multirow[t]{2}{*}{$\mathbf{p}^{\mathbf{a b}}$} \\
\hline & \multicolumn{3}{|c|}{ Abnormal n (\%) } & Jormal n (\%) & & & \\
\hline$>3$ times / week & 21 & 74,1 & 7 & 25,9 & 34 & 100.0 & \multirow[t]{3}{*}{0,934} \\
\hline$<3$ times / week & 19 & 73,1 & 7 & 26,9 & 19 & 100.0 & \\
\hline Total & 39 & 73,6 & 14 & 26,4 & 53 & 100.0 & \\
\hline
\end{tabular}

Source: Primary Data, 2020

Note: a. Chi-Square test b. $\alpha<0,05$

Table-2 shows the results of the bivariate analysis between the amount of seafood consumption and mercury levels in the hair of pregnant women. Of the 53 respondents, there were 27 respondents who consumed > 12 ounces/week of seafood, of which 20 respondents or $74.1 \%$ had mercury levels that were not normal/exceeded the threshold value $(>1 \mu \mathrm{g} / \mathrm{g}$ ). There were 26 respondents who consumed seafood $<12$ ounce/week of which 19 respondents had abnormal mercury levels in their hair or $73.1 \%$. The probability value (p) shows a value of 0.934 , not significant at $\alpha$ $0.05(\mathrm{p}>\alpha 0.05)$. The amount of fish consumption is not related to mercury levels in the hair of pregnant women.

\section{DISCUSSION}

Morrissette et al., [17] stated that the frequency of fish consumption during pregnancy has a significant positive relationship with levels of mercury in the hair of pregnant women, especially in the second and third trimesters. According to Drouillet et al., [5] the frequency of fish consumption is associated with an increase in mercury levels in the hair of pregnant women, but the levels of mercury in the hair are still within normal limits because $<1$. Frequency of fish intake during pregnancy with mercury levels in hair in pregnant women. The results of the different analysis were statistically significant $(\mathrm{p}=0.04)$. Mercury levels in hair among pregnant women with a consumption frequency of $\geq 4$ meals/week were higher than the group of pregnant women who consumed fish 1 time/week [23].
According to Gaxiola-Robles et al., [6] there was a significant relationship between the frequency of seafood consumption and increased levels of mercury in the hair of pregnant women. The frequency of seafood consumption $>2$ times/week was significant $(p=0.01)$ when compared to seafood consumption once/month. According to Kobayashi et al., [4] the frequency of seafood consumption is a factor that affects the concentration of total mercury $(\mathrm{THg})$ in the hair of pregnant women. The results of his research explained that the frequency of seafood consumption was significant with the presence of mercury levels in the hair of pregnant women. The results of the food frequency consumption (FFQ) show that pregnant women who consume seafood $<3$ times/week have mercury levels above the normal level, namely $1 \mu \mathrm{g} / \mathrm{g}$ $[4,8]$.

Pregnant women are recommended not to consume seafood > 12 ounces/week or 2 servings of canned tuna per week and no more than 6 ounces of white tuna. If the mercury content in local fish is unknown, then fish consumption should be limited to 6 ounces/week. However, a study conducted by Avon Longitudinal Study of Parents and Children (ALSPAC) using the longitudinal study method stated that pregnant women should limit their fish intake to only 340 grams per week [9]. This study is in line with the results of research by Kirk et al., [13] where the amount of seafood consumption does not have a significant effect on the hair of pregnant women. The results of measurements of mercury levels in hair are still in a safe condition, namely $0.58 \mu \mathrm{g} / \mathrm{g}$, the cause is because 
the fish diet is regulated by pregnant women, which does not exceed 12 ounces/week.

Other studies have given different results, where the concentration of mercury in umbilical cord blood, in early and late pregnancy tended to increase when the frequency of fish intake increase. It was positively related to fish consumption that exceeds the Food Drug Association (FDA) recommendation of 12 ounces/week [12] Sagiv et al., [21] stated that there is a significant relationship between the amount of seafood consumption $>2$ servings/week and the increase in mercury levels in the hair of pregnant women. According to Næss et al., [18], there was a significantly different effect between the group that was given the intervention, fish consumption of 400 grams/week and the group that was not given the intervention. The difference in treatment significantly affected the mercury levels in the hair of pregnant women, where the intervention giving fish consumption contributed to the mercury levels in the hair of pregnant women.

\section{CONCLUSION}

It is concluded that there was a significant relationship between the frequency of fish consumption and mercury levels in the hair of pregnant women. However, the amount of fish consumption was not significantly related to the hair levels of mercury. It is suggested to the public to use household materials and tools, including agricultural equipment that is mercury friendly and to provide education regarding the dangers of mercury on the health of pregnant women.

\section{REFERENCES}

1. Al-Saleh, I., Abduljabbar, M., Al-Rouqi, R., Eltabache, C., Al-Rajudi, T., Elkhatib, R., \& Nester, M. (2015). The Extent of Mercury (Hg) Exposure Among Saudi Mothers and Their Respective Infants. Environmental Monitoring and Assessment. 187(678):1-29.

2. Barghi, M., Behrooz, R. D., Esmaili-Sari, A., \& Ghasempouri, S. M. (2012). Mercury Exposure Assessment in Iranian Pregnant Women's Hair with Respect to Diet, Amalgam Filling, and Lactation. Biological Trace Element Research. 148(3): 292-301.

3. Eqani, S. A. M. A. S., Bhowmik, A. K., Qamar, S., Shah, S. T. A., Sohail, M., Mulla, S. I., ... \& Shen, H. (2016). Mercury contamination in deposited dust and its bioaccumulation patterns throughout Pakistan. Science of the Total Environment, 569, 585-593.

4. EPA. (2019). Advice About Eating Fish. Food \& Drug Administration.:Environmental Protection Agency.

5. Drouillet, P. P., Huel, G., Slama, R., Forhan, A., Sahuquillo, J., Goua, V., Thiebaugeorges, O., Foliguet, B., Magnin, G., Kaminski, M., Cordier, S., \& Charles, M. A. A. (2010). Prenatal Mercury Contamination: Relationship with Maternal
Seafood Consumption During Pregnancy and Fetal Growth in the 'EDEN Mother-Child' Cohort. British Journal of Nutrition. 104(8):10961100.

6. Gaxiola-Robles, R., Bentzen, R., Zenteno-Savín, T., Labrada-Martagón, V., Castellini, J. M., Celis, A., \& Méndez-Rodríguez, L. C. (2014). Marine Diet and Tobacco Exposure Affects Mercury Concentrations in Pregnant Women (I) from Baja California Sur, Mexico. Toxicology Reports. 1:1123-1132.

7. Güngör, O., Ozkaya, A. K., Serkan, K., Tahir, D., Sedat, I., Mehmet, D., \& Cengiz, D. (2019). Acute Mercury Poisoning in a Group of School Children. Pediatric Emergency Care. 35(10):696-699.

8. Hasnawati, A. (2019). Biomarker Dalam Toksikologi. Universitas Hasanuddin: Makassar.

9. Hibbeln, J. R., Davis, J. M., Steer, C., Emmett, P., Rogers, I., Williams, C., \& Golding, J. (2007). Maternal Seafood Consumption in Pregnancy and Neurodevelopmental Outcomes in Childhood (ALSPAC study ): an Observational Cohort Study. The Lancet. 369(2):578-585.

10. Palar. (2012). Pencemaran dan Toksikologi Logam Berat, Rhineka cipta.

11. Johnson, K. L. (2018). Sugar coating the phloem sieve element wall. Plant Physiology. 176(2):1408-1409.

12. Kim, Y., Ha, E. H., Park, H., Ha, M., Kim, Y., Hong, Y. C., \& Kim, B. N. (2018). Prenatal Mercury Exposure, Fish Intake and Neurocognitive Development During First Three Years of Life: Prospective Cohort Mothers and Children's Environmental Health (MOCEH) Study. Science of the Total Environment. 615:1192-1198.

13. Kirk, L. E., Jørgensen, J. S., Nielsen, F., \& Grandjean, P. (2017). Public Health Benefits of Hair-Mercury Analysis and Dietary Advice in Lowering Methylmercury Exposure in Pregnant Women. Scandinavian Journal of Public Health. 45(4):444-451.

14. Kobayashi, S., Reiko, K., Yasuaki, S., Yoshiya, I., Koji, O., Atsuko, A., Chihiro, M., Sachiko, I., Machiko, M., Keiko, Y., Yu, A. B., Tosiya, S., Shin, Y, Shoji, F. N., Tomohiko, I., \& Hiroshi, N. (2019). Association of Blood Mercury Levels During Pregnancy with Infant Birth Size by Blood Selenium Levels in the japan Environment and Children's Study: A Prospective Birth Cohort. Environmental International. 125:418-429.

15. Miklavčič, A., Cuderman, P., Mazej, D., Snoj Tratnik, J., Krsnik, M., Planinšek, P., \& Horvat, M. (2011). Biomarkers of Low-Level Mercury Exposure Through Fish Consumption in Pregnant and Lactating Slovenian Women. Environmental Research. 111(8):1201-1207.

16. Mínguez-Alarcón, L., Afeiche, M. C., Williams, P. L., Arvizu, M., Tanrikut, C., Amarasiriwardena, C. J., \& Chavarro, J. E. (2018). Hair Mercury (Hg) 
Levels, Fish Consumption and Semen Parameters Among Men Attending a Fertility Center. International Journal of Hygiene and Environmental Health. 221(2):174-182.

17. Morrissette, J., Takser, L., St-Amour, G., Smargiassi, A., Lafond, J., \& Mergler, D. (2004). Temporal Variation of Blood and Hair Mercury Levels in Pregnancy in Relation to Fish Consumption History in a Population Living Along the St. Lawrence River. Environmental Research. 95(3):363-374.

18. Næss, S., Marian, K., Lisbeth, D., Ive, N., Lisa, K. M., Michael, S. B., Josef, D. R., \& Maria, W. M. (2020). Effects of Seafood Consumption on Mercury Exposure in Norwegian Pregnant Women: A Randomized Controlled Trial. Environment International, 141(4):105-109.

19. Ramon, R., Ballester, F., Aguinagalde, X., Amurrio, A., Vioque, J., Lacasana, M., ... \& Iniguez, C. (2009). Fish consumption during pregnancy, prenatal mercury exposure, and anthropometric measures at birth in a prospective mother-infant cohort study in Spain. The American journal of clinical nutrition, 90(4), 1047-1055.

20. Reza, Karimuna, S. R., \& Fachlevy, A. F. (2016). Analisis Perbedaan Potensi Risiko Keterpaparan Merkuri Pada Masyarakat Di Desa Tahi Ite Kecamatan Rarowatu Kabupaten Bombana Tahun 2016. Jimkesmas. 1(4):1-13.

21. Sagiv, S. K., Thurston, S. W., Bellinger, D. C., Amarasiriwardena, C., \& Korrick, S. A. (2012). Prenatal Exposure to Mercury and Fish Consumption During Pregnancy and Attention-
Deficit/Hyperactivity Disorder-Related Behavior in Children. Archives of Pediatrics and Adolescent Medicine. 166(12):1123-1131.

22. Sandra de Souza, H., Marcelo, O., Cecile, Renata, F., Paulo, C. B., Ana, S., \& Decio, Y. (2020). Mercury Exposure through Fish Consumption in Traditional Communities in the Brazilian Northern Amazon. International Journal Environment Research Public Health. 17(15):52-69.

23. Salehi, Z., \& Esmaili-Sari, A. (2010). Hair Mercury Levels in Pregnant Women in Mahshahr, Iran: Fish Consumption as a Determinant of Exposure. Science of the Total Environment. 408(20):4848-4854.

24. Sarah, E. D., Beth, J. F., Ernesto, J. O., John, A. G., Julio, M. A. F., Axel, B., William, K. Y. P., \& Heileen, H. (2014). River Transport of Mercury from Artisanal and Small-Scale Gold Mining and Risks for Dietary Mercury Exposure in Madre de Dios, Peru. Environmental Science Processes \& Impact. 120-128.

25. Schaefer, A. M., Zoffer, M., Yrastorza, L., Pearlman, D. M., Bossart, G. D., Stoessel, R., \& Reif, J. S. (2019). Mercury Exposure, Fish Consumption, and Perceived Risk Among Pregnant Women in Coastal Florida. International Journal of Environmental Research and Public Health. 16(24).

26. Widiowati. (2008). Efek toksik logam Pencegahan dan Penanggulangan Pencemaran, Andy: Yogyakarta

27. Yoshida, M. (2002). Placental to Fetal Transfer of Mercury and Fetotoxicity. Tohoku Journal of Experimental Medicine. 196:79-88. 